\title{
Forage Productivity, Competition Indices and Economics of Forage Millet and Guar As Affected By Intercropping Pattern and Nitrogen Fertilizer under Sandy Soil Conditions
}

\author{
Ahmed M. Abd Allah ${ }^{* 1}$; Hend H. M. Hassan ${ }^{2}$ and M. M. Awad ${ }^{1}$ \\ ${ }^{1}$ Crop Intensification Dept., Field Crops Res. Inst., Agric. Res. Cent. (ARC), Giza, Egypt \\ ${ }^{2}$ Forage Crops Res. Dept., Field Crops Res. Inst., Agric. Res. Cent. (ARC), Giza, Egypt
}

Received: $17 / 11 / 2020$

\begin{abstract}
Two field experiments were carried out during two successive summer seasons of two year 2018 and 2019 at Ismailia Agricultural Research Station, Agric. Research Center (ARC) to study the effect of intercropping patterns of forage millet $(\mathrm{M})$ and guar $(\mathrm{G})$ i.e. one row of forage millet for one row of guar (1M:1G), one row of forage millet for two row of guar $(1 \mathrm{M}: 2 \mathrm{G})$, two rows of forage millet for one row of guar $(2 \mathrm{M}: 1 \mathrm{G})$ and two rows of forage millet for two rows of guar $(2 \mathrm{M}: 2 \mathrm{G})$, respectively. Sole crops of forage millet and guar were included as check treatment to compare yields of intercropped patterns. Three nitrogen levels $\left(45,60\right.$ and $\left.75 \mathrm{~kg} \mathrm{~N} \mathrm{fad}^{-1}\right)$ were applied for each in plot. The intercropping pattern of $(2 \mathrm{M}: 1 \mathrm{G})$ gave the highest total fresh $\left(32.48\right.$ and 27.91 ton fad $\left.^{-1}\right)$ and dry $(7.12$ and 5.93 ton $\mathrm{fad}^{-1}$ ) forage yields in the $1^{\text {st }}$ and the $2^{\text {nd }}$ seasons, respectively than all other intercropping patterns. Increasing the level of $\mathrm{N}$ from 45 to $75 \mathrm{~kg} \mathrm{~N} \mathrm{fad}^{-1}$ gradually increased each of the fresh and dry forage yields of the three cuts as well as their totals for the two growing seasons. The contribution percentage of forage millet in dry yield for the three cuts of any intercropping system was high, whereas that of guar was low than the expected in both seasons. Also, the addition of to $75 \mathrm{~kg} \mathrm{~N}_{\mathrm{fad}}{ }^{-1}$ gave the highest contribution rate of forage millet, while the contribution rate of guar was gradually decreased with each increase level, this is clear in the $1^{\text {st }}$ cut in both seasons. The $(2 \mathrm{M}: 1 \mathrm{G})$ intercropping pattern was exhibited higher LER, competitive indices values and economic compared to the other intercropping patterns. Generally, increasing nitrogen levels tremendously improved total LER, competitive indices values and economic especially for forage millet as major component of intercropping system. From this study, it is inferred that intercropping of forage millet with guar at (2M:1G) planting pattern and fertilized with $75 \mathrm{~kg} \mathrm{~N}$ fad. ${ }^{-1}$ give higher income, better land use efficiency and thus enhanced sustainability of crop production than sole culture of each crop species.
\end{abstract}

Keywords: Intercropping, competition indices, forage millet, guar, CR, LER and LEC

\section{INTRODUCTION}

There is need to meet the fodder demand of increasing number of livestock and also enhance their productivity from the meager land. Since human population is increasing at alarming rate, the per capita availability of land is also declining which leads more pressure on meager land to fulfill the food requirement of the larger masses. Hence, it is big challenge in front of us to utilize the meager land wisely with its fullest potential to produce the fodders to the animals. That could be achieved by adopting suitable cropping systems (Kumar et al., 2012).

The intercropping system with forage crops provides potential alternative to overcome the fodder problem as it utilizes the resources more efficiently. It also provides the balanced diet to the animals due to inclusion of legume and cereal fodder crops together. Intercropping is the cultivation of two or more crops simultaneously on the same field, with row arrangement having different growth habits, canopy structure, rooting pattern and offering little or no mutual competition world (Iqbal et al., 2015). The morphological and physiological differences among intercrop components result in their ability to occupy different niches. Thus, environmental resources could be more efficiently utilized and converted to biomass by mixed stands of crops than by pure stands (Iqbal $e t$ al., 2017). Moreover, Reza et al. (2013) found that under intercropping system, the highest fresh and dry weight of sorghum fodder belonged to additive proportions of sorghum. Hassan (2003) showed that the contribution percentage maize in dry yield of any intercropping treatment was high, whereas that of cowpea was low than expected. Also, Oseni (2010) reported that the $2 \mathrm{~S}: 1 \mathrm{C}$ planting arrangement exhibited higher LER, competitive indices values and SPI compared to other planting arrangements and to sole crop. Lesoing and Francis (1999) reported that the intercropping systems, sorghum has been found to be the dominant crop and more competitive for applied farm resources than cluster bean. Furthermore, shading by sorghum affects the morphological development and forage quality of cluster bean when intercropped with sorghum.

Nitrogen plays an important role in increasing forage production but, the cost of nitrogen fertilizers is very expensive; it becomes imperative to substitute nitrogen to some other cheaper sources, which may partially meet the nitrogen required by the crop. A useful method of the input of chemical fertilizers in agriculture and to control soil and water pollution may be represented by the use intercropping system (Hassan, 2017). Increasing nitrogen to level of $160 \mathrm{~kg}$ per hectare resulted to the increase in yield for forage dry weight of sorghum, but there was no significant difference between the two treatments of 160 and 240 $\mathrm{kg}$ nitrogen per hectare (Reza et al., 2012). Safari et al. (2014) stated that the different nitrogen levels significantly influenced the total fresh and dry matter 
content of forage crops. Also, Javanmard et al. (2014) studied that nitrogen consumption increased forage yield and cereal equivalent yield. Land equivalent ratio, relative crowding coefficient, aggressivity, competitive ratio and intercropping advantage in cereal was better than legume. Cereal had positive competitive indicate, but in legume was negative in study on barley and pea intercropping. Moreover, Muhammad et al. (2006) stated that high nitrogen level in maize intercropped with cowpea can affect photosynthesis resulted in a decrease in the cowpea's mass due to corn shading. This can weaken the cowpea's gesture, growth and competitiveness in these mixtures. Generally, maize was the dominant species in all mixtures.

The objective of this study was to investigate the most appropriate intercropping pattern and better $\mathrm{N}$ level for producing the highest forage yield and land use efficiency as well as economic evaluation from the studied intercropping pattern.

\section{MATERIALS AND METHODS}

\section{Site Description:}

Field experiments were conducted during the summer season of successive years (2018-2019) at Ismailia Agricultural Research Station (Sandy Soil), Agric. Research Center (ARC). Mechanical and chemical analyses of the experimental site area presented in Table (1).

\section{Experimental design:}

A split plot experimental design, with three replicates, was used to evaluate four planting intercropping patterns of forage millet (Pennisetum americanum (L.) K. S chum) c.v. Shandawil 1 and guar (Cyamopsis tetragonoloba L.) local c.v and three levels of $\mathrm{N}$ fertilizer. Main plots were assigned to tested the intercropping patterns while, the $\mathrm{N}$ levels fertilizer were tested in the subplots.

\section{Intercropping treatments:}

1- Sole of forage millet with a seeding rate $25 \mathrm{~kg} \mathrm{fad}^{-1}$

2- Sole of guar with a seeding rate $20 \mathrm{~kg} \mathrm{fad}^{-1}$

3- One row of forage millet alternated with one row of guar i.e. (1M:1G) intercropping patterns.

4- One row of forage millet alternated with twos row of guar i.e. (1M:2G) intercropping patterns.

5- Two rows of forage millet alternated with one row of guar i.e. (2M:1G) intercropping patterns.

6- Two rows of forage millet alternated with two rows of guar i.e. (2M:2G) intercropping patterns.

\section{Nitrogen fertilization levels:}

1 - $45 \mathrm{~kg} \mathrm{~N}$ fad $^{-1}$

2- $60 \mathrm{~kg} \mathrm{~N}$ fad $^{-1}$

3- $75 \mathrm{~kg} \mathrm{~N}$ fad $^{-1}$

\section{Management and sampling:}

The experimental plots were sown on $17^{\text {th }}$ and $20^{\text {th }}$ May in the year of 2018 and 2019, respectively. The plot size was $9 \mathrm{~m}^{2}$ consisted 12 rows each of $3.6 \mathrm{x}$ $2.5 \mathrm{~m}$. Nitrogen fertilizer was applied in the form of Ammonium Nitrate $(33.5 \% \mathrm{~N})$ at the different levels under study and divided into three equal doses. The first dose was added after 21 days from sowing, the second and the third doses were added after the first and the second cuts, respectively. Each of calcium superphosphate $\left(15.5 \% \mathrm{P}_{2} \mathrm{O}_{5}\right)$ at the rate of $200 \mathrm{~kg} \mathrm{fad}^{-1}$ and potassium sulphate $\left(48 \% \mathrm{~K}_{2} \mathrm{O}\right)$ at the rate of $50 \mathrm{~kg}$ fad $^{-1}$ were applied before sowing. The preceding crop was wheat in both seasons. Three cuts were taken in both seasons, the first cut was after 56 days of planting and the following cuts were done 35 days intervals in both seasons. The other agronomic practices were done as recommended. At cutting time, plants of an area 4.5 $\mathrm{m}^{2}$ were cut from the six inner rows to determine the following data:

\section{Fresh and dry forage yields fad ${ }^{-1}$}

Fresh forage yield for each sole crop as well as for both components in case of intercropping was determined. Samples of $250 \mathrm{~g}$ fresh forage were oven dried at $105^{\circ} \mathrm{C}$ up to constant weight to estimate dry forage yield ton $\mathrm{fad}^{-1}$. Data for fresh and dry forage yields as $\left(\right.$ ton $\left.\mathrm{fad}^{-1}\right)\left(\mathrm{fad}=\right.$ faddan $\left.=4200 \mathrm{~m}^{2}\right)$.

\section{Botanical composition}

Calculate the contribution percentage of both components in the average of the combined intercrop dry forage yield for the three cuts of both seasons.

\section{Competitive indices}

The competitive behavior of component crops in different forage millet - guar planting patterns was determined in terms of land equivalent ratio, Land equivalent coefficient, relative crowding coefficient, aggressivity, competitive ratio and system productivity index.

\section{Land equivalent ratio (LER)}

This gives an indication to the relative land area sole cropping that is required, to produce the same yields achieved by intercropping. The value of unity is the critical value. When the LER is greater than one, the intercropping favors the growth and yield of the species. On another hand, when LER is lower than one the intercropping negatively affects the growth and yield of the plants grown in mixture. It was determined for forage millet and guar yield recorded per faddan according to the equation as follows:

$$
\begin{aligned}
& \mathrm{LER}=\left(\mathrm{LE}_{\mathrm{m}}\right)_{+}\left(\mathrm{LE}_{\mathrm{g}}\right) \\
& \mathrm{LE} \mathrm{m}_{\mathrm{m}}=\left(\mathrm{Y}_{\mathrm{mi}} / \mathrm{Y}_{\mathrm{mm}}\right)
\end{aligned} \text { and } \quad \mathrm{LE}_{\mathrm{g}}=\left(\mathrm{Y}_{\mathrm{gi}} / \mathrm{Y}_{\mathrm{gg}}\right)
$$

Where $Y_{\mathrm{mm}}$ and $Y_{\mathrm{gg}}$ are the yields per faddan of forage millet and guar, respectively as sole crop. $\mathrm{Y}_{\mathrm{mi}}$ and $\mathrm{Y}_{\mathrm{gi}}$ are the yields of forage millet and guar, respectively as intercrops component (Mead and Willey, 1980). Land Equivalent Coefficient (LEC)

A measure of interaction concerned with the strength of relationship was calculated thus, LEC = $(\mathrm{LEm}) \times\left(\mathrm{LE}_{\mathrm{g}}\right)$. Where $\mathrm{LEC}_{\mathrm{m}}=$ partial LER of main crop and $\mathrm{LEC}_{\mathrm{g}}=$ partial LER of intercrop (Aditiloye $e t$ al., 1983). For a two- crop mixture the minimum expected productivity Coefficient (PC) is $25 \%$ that is a yield advantage is obtained if LEC exceeds 0.25 .

\section{Relative Crowding Coefficient (RCC)}

Which is a measure of the relative dominance of one species over the other in a mixture (Willey and Rao, 1980) was calculated as: $\mathrm{K}=\left(\mathrm{K}_{\mathrm{m}} \times \mathrm{K}_{\mathrm{g}}\right)$ 
$\mathrm{K}_{\mathrm{m}}=\left(\mathrm{Y}_{\mathrm{mi}} \times \mathrm{Z}_{\mathrm{gm}}\right) /\left[\left(\mathrm{Y}_{\mathrm{mm}^{-}} \mathrm{Y}_{\mathrm{mi}}\right) \times \mathrm{Z}_{\mathrm{mm}}\right]$ and $\mathrm{K}_{\mathrm{g}}=\left(\mathrm{Y}_{\mathrm{gi}} \times\right.$ $\left.\mathrm{Z}_{\mathrm{mm}}\right) /\left[\left(\mathrm{Y}_{\mathrm{gg}}-\mathrm{Y}_{\mathrm{gi}}\right) \times \mathrm{Z}_{\mathrm{gm}}\right]$

Where $Z_{m m}$ and $Z_{g m}$ were the proportion of forage millet and guar in the mixture, respectively. The crop component that had a higher coefficient was said to be dominant. If the coefficient of a particular crop is less than, equal to or greater than 1, then that species has produced less yield, the same yield, or more than "expected", respectively (Willey and Rao, 1980).

\section{Aggressivity (A):}

Is a measure of competitive relationships between two crops in mixed cropping (Willey, 1979). This was expressed according to Dhima el al. (2007) as follows: $A_{\mathrm{m}}=\left(\mathrm{Y}_{\mathrm{mi}} / \mathrm{Y}_{\mathrm{mm}} \times \mathrm{Z}_{\mathrm{mm}}\right)-\left(\mathrm{Y}_{\mathrm{gi}} / \mathrm{Y}_{\mathrm{gg}} \times \mathrm{Z}_{\mathrm{gm}}\right)$ and $\mathrm{A}_{\mathrm{g}}=\left(\mathrm{Y}_{\mathrm{gi}} / \mathrm{Y}_{\mathrm{gg}} \times \mathrm{Z}_{\mathrm{gm}}\right)-\left(\mathrm{Y}_{\mathrm{mi}} / \mathrm{Y}_{\mathrm{mm}} \times \mathrm{Z}_{\mathrm{mm}}\right)$

Thus if $\mathrm{A}_{\mathrm{m}}=0$, both crops are equally competitive, if $A_{g}$ is positive, then it is dominant and if $A_{m}$ is negative, then forage millet is weak.

\section{Competitive ratio (CR)}

Measures the ratio of individual $\mathrm{LER}_{\mathrm{m}}$ of the two component crops and the proportion in which they were sown in the mixture. This gives a more desirable competitive ability for the crops and is advantageous as an index over K (Dhima el al., 2007). The competitive ratio for forage millet and guar in mixture was calculated by the formula proposed by (Willey et al., 1980) as follows: $\mathrm{CR}_{\mathrm{m}}=\left(\mathrm{LE}_{\mathrm{m}} / \mathrm{LE}_{\mathrm{g}}\right)\left(\mathrm{Z}_{\mathrm{gm}} / \mathrm{Z}_{\mathrm{mm}}\right)$ and $\mathrm{CR}_{\mathrm{g}}=\left(\mathrm{LE}_{\mathrm{g}} / \mathrm{LE}_{\mathrm{m}}\right)\left(\mathrm{Z}_{\mathrm{mm}} / \mathrm{Z}_{\mathrm{gm}}\right)$ System Productivity Index (SPI):

Is calculated as $\mathbf{S P I}=\left(\mathrm{Y}_{\mathrm{mm}} / \mathrm{Y}_{\mathrm{gg}} \times \mathrm{Y}_{\mathrm{gi}}\right)+\mathrm{Y}_{\mathrm{mi}}$ (Odo, 1991).

Where $\mathrm{SPI}=$ System productivity index, $\mathrm{Y}_{\mathrm{mm}}$ and $\mathrm{Y}_{\mathrm{gg}}$ $=$ Mean yield of forage millet and guar in sole plots, $\mathrm{Y}_{\mathrm{mi}}$ and $\mathrm{Y}_{\mathrm{gi}}=$ yield of forage millet and guar in intercropping patterns.

\section{Economic Evaluation:}

The economic evaluation included the following three parameters:

$>$ Average of input variables and the total costs of intercropping patterns production including levels of $\mathrm{N}$ fertilizer and other culture practices applied during the growth stages of intercropping patterns (average land rent is not included)

$>$ Net farm income of intercropping patterns for various $\mathrm{N}$ levels.

$>$ Net farm return intercropping patterns production as affected by applied treatments. It's calculated as the difference between the forage yield value (according to the actual price) and the total costs. All fertilizers and seed prices and the costs of all farm operations are based on the official and the actual market prices determine by Egypt Ministry of Agriculture (Economic Reports, 2014). Total costs included values of production tools and requirements such as seeds, fertilizers, irrigation, man, power, machinery and other general or different costs without land rent average.

\section{Statistical analysis:}

The intercropping treatments, fertilizer applications as well as their interactions of were analyzed statistically using Fisher's analysis of variance technique and LSD test used to compare the treatments means at 0.05 probability level (Steel et al., 1997).

Table (1): Mechanical and chemical analyses of the experimental soil sites during the two summer successive seasons of two year 2018 and 2019

\begin{tabular}{|c|c|c|}
\hline Soil characteristics & $\begin{array}{c}\text { season } \\
2018\end{array}$ & $\begin{array}{c}\text { Season } \\
2019\end{array}$ \\
\hline \multicolumn{3}{|c|}{ Mechanical analysis } \\
\hline Coarse sand \% & 74.00 & 72.50 \\
\hline Fine sand \% & 19.50 & 19.65 \\
\hline Silt \% & 2.45 & 3.50 \\
\hline Clay \% & 3.45 & 4.35 \\
\hline Texture & Sandy & Sandy \\
\hline \multicolumn{3}{|c|}{ Chemical analysis } \\
\hline PH & 7.86 & 7.90 \\
\hline EC dS m ${ }^{-1}$ & 0.95 & 1.04 \\
\hline Organic matter \% & 0.42 & 0.53 \\
\hline \multicolumn{3}{|c|}{ Soluble cations (mmolic $\left.\mathbf{L}^{-1}\right)$} \\
\hline $\mathrm{Ca}^{2+}$ & 4.30 & 4.39 \\
\hline $\mathrm{Mg}^{2+}$ & 1.82 & 1.90 \\
\hline $\mathrm{Na}^{+}$ & 2.43 & 2.51 \\
\hline $\mathbf{K}^{+}$ & 0.95 & 1.60 \\
\hline \multicolumn{3}{|c|}{ Soluble anions (mmolic $\mathbf{L}^{-1}$ ) } \\
\hline $\mathrm{HCO3}^{-}$ & 2.15 & 2.28 \\
\hline $\mathrm{CL}^{-}$ & 2.65 & 2.75 \\
\hline $\mathrm{SO}^{2-}$ & 4.70 & 5.37 \\
\hline \multicolumn{3}{|c|}{ Available macro nutrients (ppm) } \\
\hline $\mathbf{N}$ & 18.21 & 21.32 \\
\hline $\mathbf{P}$ & 4.85 & 5.78 \\
\hline $\mathbf{K}$ & 63.45 & 73.20 \\
\hline \multicolumn{3}{|c|}{ DTPA- extractable $\left(\mathrm{mg} \mathrm{kg}^{-1}\right)$} \\
\hline $\mathbf{F e}$ & 1.76 & 1.82 \\
\hline Mn & 1.44 & 1.45 \\
\hline $\mathbf{Z n}$ & 0.37 & 0.50 \\
\hline
\end{tabular}

\section{RESULTS AND DISCUSSION}

Fresh and dry forage yields $\left(\mathrm{t} \mathrm{fad}^{-\mathbf{1}}\right)$

The results presented in Table (2), indicate of that there were significant differences in the total fresh and dry forage yields among all intercropping patterns and each cut at first and second seasons. Forage millet as grasses gave higher fresh and dry forage yields compared with guar forage yields as legume for the total and three cuts individually in both seasons, that presumably due to the absent of competition from companion crop. Similar finding were reported by Poodineh et al. (2014). The highest values of total fresh and dry forage yields were produced by planting 2M:1G (32.48 and 7.12 ton $\mathrm{fad}^{-1}$ in the first season) and (27.91 and 5.93 ton fad $^{-1}$ in the second season), respectively compared with all another intercropping. 
Table (2): Effect of intercropping pattern, nitrogen level and their interaction on fresh and dry forage yields of forage millet and guar

\begin{tabular}{|c|c|c|c|c|c|c|c|c|c|c|c|c|c|c|c|c|}
\hline \multirow{3}{*}{$\begin{array}{l}\text { Main effects and } \\
\text { interactions }\end{array}$} & \multicolumn{8}{|c|}{ Fresh forage yield $\left(\mathrm{t} \mathrm{fad}^{-1}\right)$} & \multicolumn{8}{|c|}{ Dry forage yield $\left(t\right.$ fad $\left.^{-1}\right)$} \\
\hline & \multicolumn{4}{|c|}{ First season } & \multicolumn{4}{|c|}{$\begin{array}{l}\text { Second season } \\
\end{array}$} & \multicolumn{4}{|c|}{ First season } & \multicolumn{4}{|c|}{$\begin{array}{l}\text { Second season } \\
\end{array}$} \\
\hline & $\overline{1^{\text {st }} \text { cut }}$ & $2^{\text {nd }}$ cut & $3^{\text {rd }}$ cut & Total & $1^{\text {st }}$ cut & $2^{\text {nd }}$ cut & $3^{\text {rd }}$ cut & Total & $1^{\text {st }}$ cut & $2^{\text {nd }}$ cut & $3^{\text {rd }}$ cut & Total & $1^{\text {st }}$ cut & $2^{\text {nd }}$ cut & $3^{\text {rd }}$ cut & Total \\
\hline \multicolumn{17}{|l|}{ Intercropping pattern (A) } \\
\hline Forage millet sole (A1) & 13.36 & 10.32 & 7.19 & 30.88 & 12.80 & 8.68 & 5.00 & 26.48 & 2.65 & 2.31 & 1.86 & 6.28 & 2.52 & 1.88 & 1.20 & 5.60 \\
\hline Guar sole (A2) & 6.20 & 4.22 & 1.49 & 11.92 & 4.84 & 3.82 & 1.81 & 10.48 & 0.87 & 0.63 & 0.24 & 1.75 & 0.90 & 0.67 & 0.34 & 1.91 \\
\hline 1: 1 Forage millet/guar (A3) & 12.41 & 7.98 & 4.85 & 25.24 & 12.75 & 7.32 & 4.13 & 24.21 & 2.43 & 1.96 & 1.31 & 5.71 & 2.34 & 1.64 & 0.94 & 4.93 \\
\hline $1: 2$ Forage millet/guar (A4) & 10.59 & 6.73 & 3.77 & 21.10 & 11.56 & 6.31 & 3.55 & 21.44 & 1.89 & 1.44 & 0.96 & 4.29 & 1.89 & 1.27 & 0.74 & 3.90 \\
\hline 2:1 Forage millet/guar (A5) & 15.11 & 10.77 & 6.59 & 32.48 & 14.18 & 8.93 & 4.79 & 27.91 & 2.94 & 2.40 & 1.77 & 7.12 & 2.77 & 1.99 & 1.18 & 5.93 \\
\hline 2:2 Forage millet/guar (A6) & 13.98 & 9.54 & 4.69 & 28.22 & 13.03 & 7.55 & 4.36 & 24.95 & 2.52 & 2.04 & 1.42 & 5.99 & 2.38 & 1.66 & 0.97 & 5.01 \\
\hline LSD 0.05 & 1.09 & 0.95 & 0.77 & 4.07 & 1.03 & 0.84 & 0.38 & 2.63 & 0.33 & 0.26 & 0.20 & 0.58 & 0.31 & 0.31 & 0.18 & 0.82 \\
\hline \multicolumn{17}{|l|}{ Nitrogen level (B) } \\
\hline $45 \mathrm{~kg} \mathrm{~N} \mathrm{fad}^{-1}$ (B1) & 9.94 & 6.61 & 4.02 & 20.58 & 9.64 & 5.24 & 3.28 & 18.17 & 1.86 & 1.36 & 0.95 & 4.18 & 1.81 & 1.04 & 0.72 & 3.58 \\
\hline $60 \mathrm{~kg} \mathrm{~N} \mathrm{fad}^{-1}(\mathrm{~B} 2)$ & 12.24 & 8.70 & 4.96 & 25.91 & 11.85 & 7.38 & 4.04 & 23.27 & 2.24 & 1.96 & 1.30 & 5.51 & 2.13 & 1.64 & 0.92 & 4.69 \\
\hline $75 \mathrm{~kg} \mathrm{Nfad}^{-1}$ (B3) & 13.64 & 9.47 & 5.30 & 28.42 & 13.10 & 8.69 & 4.50 & 26.29 & 2.55 & 2.07 & 1.53 & 6.16 & 2.46 & 1.87 & 1.04 & 5.37 \\
\hline LSD 0.05 & 0.63 & 0.66 & 0.51 & 1.69 & 0.70 & 0.37 & 0.14 & 1.47 & 0.10 & 0.12 & 0.09 & 0.18 & 0.08 & 0.07 & 0.03 & 0.33 \\
\hline \multicolumn{17}{|l|}{ Interaction } \\
\hline A1B1 & 10.63 & 7.3 & 5.56 & 23.49 & 10.93 & 6.31 & 4.28 & 21.52 & 2.26 & 1.83 & 1.47 & 5.56 & 2.28 & 1.34 & 1.00 & 4.63 \\
\hline A1B2 & 14.27 & 11.12 & 7.2 & 32.59 & 12.89 & 9.16 & 5.06 & 27.12 & 2.65 & 2.53 & 1.9 & 7.08 & 2.51 & 1.97 & 1.21 & 5.70 \\
\hline A1B3 & 15.17 & 12.55 & 8.82 & 36.55 & 14.58 & 10.56 & 5.65 & 30.80 & 3.06 & 2.58 & 2.22 & 7.87 & 2.77 & 2.33 & 1.38 & 6.48 \\
\hline A2B1 & 5.97 & 3.81 & 1.4 & 11.19 & 3.45 & 2.91 & 1.66 & 8.02 & 0.79 & 0.50 & 0.17 & 1.47 & 0.78 & 0.56 & 0.30 & 1.65 \\
\hline A2B2 & 6.01 & 4.23 & 1.49 & 11.73 & 5.02 & 4.24 & 1.88 & 11.15 & 0.90 & 0.67 & 0.27 & 1.85 & 0.93 & 0.70 & 0.35 & 1.99 \\
\hline A2B3 & 6.62 & 4.64 & 1.58 & 12.84 & 6.05 & 4.32 & 1.8 & 12.27 & 0.92 & 0.73 & 0.29 & 1.95 & 0.99 & 0.73 & 0.36 & 2.09 \\
\hline A3B1 & 10.34 & 6.63 & 3.84 & 20.82 & 11.2 & 5.52 & 3.29 & 20.01 & 2.05 & 1.53 & 1.01 & 4.60 & 2.07 & 1.18 & 0.75 & 4.00 \\
\hline A3B2 & 13.31 & 7.91 & 4.94 & 26.17 & 12.97 & 7.31 & 4.13 & 24.41 & 2.47 & 2.15 & 1.36 & 5.98 & 2.30 & 1.73 & 0.96 & 5.00 \\
\hline A3B3 & 13.58 & 9.39 & 5.76 & 28.74 & 14.08 & 9.14 & 4.96 & 28.2 & 2.76 & 2.20 & 1.58 & 6.54 & 2.65 & 2.02 & 1.11 & 5.79 \\
\hline A4B1 & 9.37 & 5.61 & 3.5 & 18.48 & 9.66 & 4.94 & 2.97 & 17.58 & 1.55 & 0.89 & 0.73 & 3.17 & 1.45 & 0.77 & 0.59 & 2.82 \\
\hline A4B2 & 10.36 & 7 & 3.91 & 21.28 & 12.08 & 5.93 & 3.64 & 21.66 & 1.93 & 1.68 & 0.99 & 4.60 & 1.94 & 1.43 & 0.76 & 4.14 \\
\hline A4B3 & 12.05 & 7.60 & 3.92 & 23.58 & 12.94 & 8.08 & 4.06 & 25.09 & 2.19 & 1.74 & 1.17 & 5.10 & 2.26 & 1.62 & 0.86 & 4.75 \\
\hline A5B1 & 11.99 & 8.50 & 5.68 & 26.19 & 12.11 & 6.56 & 3.86 & 22.54 & 2.36 & 1.79 & 1.28 & 5.44 & 2.38 & 1.36 & 0.91 & 4.65 \\
\hline A5B2 & 15.35 & 11.87 & 6.86 & 34.09 & 14.56 & 9.50 & 5.02 & 29.08 & 2.95 & 2.52 & 1.81 & 7.28 & 2.65 & 2.09 & 1.22 & 5.97 \\
\hline A5B3 & 17.98 & 11.94 & 7.24 & 37.17 & 15.88 & 10.72 & 5.51 & 32.11 & 3.52 & 2.90 & 2.22 & 8.64 & 3.27 & 2.51 & 1.40 & 7.19 \\
\hline A6B1 & 11.37 & 7.82 & 4.16 & 23.35 & 10.50 & 5.21 & 3.61 & 19.33 & 2.13 & 1.62 & 1.08 & 4.83 & 1.89 & 1.05 & 0.77 & 3.72 \\
\hline A6B2 & 14.13 & 10.09 & 5.40 & 29.63 & 13.56 & 8.12 & 4.54 & 26.23 & 2.57 & 2.22 & 1.48 & 6.28 & 2.44 & 1.91 & 1.00 & 5.36 \\
\hline A6B3 & 16.46 & 10.72 & 4.51 & 31.69 & 15.04 & 9.32 & 4.94 & 29.31 & 2.87 & 2.28 & 1.70 & 6.86 & 2.79 & 2.02 & 1.13 & 5.95 \\
\hline LSD 0.05 & 1.55 & 1.63 & 1.25 & 4.16 & 0.80 & 0.91 & 0.35 & 2.77 & 0.26 & 0.30 & 0.23 & 0.46 & 0.21 & 0.17 & 0.07 & 1.14 \\
\hline
\end{tabular}


On the contrary, the lowest values of total fresh and dry forage yields $\left(21.10\right.$ and 4.29 ton $\mathrm{fad}^{-1}$ in the first season) and (21.44 and 3.90 ton $\mathrm{fad}^{-1}$ in the second season), respectively were produced by planting $1 \mathrm{M}: 2 \mathrm{G}$, also this was true in the three cuts. Dwivedi et al. (2015) noted that the grass component, with relatively higher growth rate, higher advantage, is favored in the competition with the association legume. Similarly, Mead and Willey (1980) had earlier reported that in a sorghum/cowpea intercrop, not only the yield of cowpea was depressed by sorghum but also cowpea depressed the yield of sorghum. However, attribute the depression in yield of cereal/legume mixtures to shading by cereal (Chui and Shibles, 1983).

Concerning forage yields as influenced by nitrogen fertilizers, an increase in $\mathrm{N}$ level from 45 to 60 and $75 \mathrm{~kg} \mathrm{~N}$ fad $^{-1}$ produced a significant increase in fresh and dry forage yields, this was clear for the total and the three cuts. There are many reports considering the positive effect of nitrogen fertilizer on forage yield. Homayooni et al. (2005) reported that increasing nitrogen level increased in the height, the number of tillers and the leaf area of millet plants and this ultimately leads to a rise in dry matter. On the other hand, Hannah and Gohain (2016) found that on low-N soils, the non-legume is often suppressed, and on high$\mathrm{N}$ soils the vigorous growth of the non-legume usually causes to dominate it over the legume by shading.

As shown in Table (2), it is evident that interaction between intercropping pattern and nitrogen level had significant effect on forage yields for the total and the three cuts of both seasons. In general, fresh and dry forage yields for sole forage millet, sole guar and their intercropping patterns were increased due to increasing nitrogen level. Sole Forage millet gave higher total fresh and dry forage yields compare with sole guar total forage yield under any level of nitrogen fertilizer in both seasons. Hassan et al. (2017) stated that the grass component, with relative higher growth rate, higher advantage, is favored in the competition with the association legume. The intercropping pattern (2M:1G) gave the highest values total fresh (37.17 and $32.11)$ and dry (8.64 and 7.19 ton fad $^{-1}$ ) of forage yields with adding $75 \mathrm{~kg} \mathrm{~N}$ fad $^{-1}$ in both seasons, respectively. While, the intercropping pattern (1M:2G) gave the lowest values of total fresh and dry forage yields (18.48 and 3.17 ton $\left.\mathrm{fad}^{-1}\right)$ in the first season and (17.58 and 2.82 ton $\left.\mathrm{fad}^{-1}\right)$ in the second season when fertilized by the lowest level of the $\mathrm{N}\left(45 \mathrm{~kg} \mathrm{~N} \mathrm{fad}^{-1}\right)$, respectively.

\section{Botanical Composition}

The illustrated graphics in Figs. (1, 2, 3, 4, 5 and 6) indicated that, the contribution of forage millet in dry forage yield of any intercropping patterns was higher than that of guar (the component proportion percentage). Hassan et al. (2017) noted that guar yields were generally reduced by intercropping especially in the second and third cuts. Also, Clark and Myers (1994) stated that guar in narrow strips yielded less than in wide strips or mono crop, and attributed the reduction to fact that in the narrow strips, both of the guar were bordered by non-legume, and therefore competition were greater than in the wide strips.

The results revealed that the contribution rate of forage millet component of dry forage yield was gradually increased with the increase in nitrogen level from 45 to $75 \mathrm{~kg} \mathrm{~N}^{-1}$. The addition of to $75 \mathrm{~kg} \mathrm{~N}$ $\mathrm{fad}^{-1}$ gave the highest contribution rate of forage millet component. While we find the opposite in the case the contribution rate of guar component of dry forage yield was gradually decreased with each level of nitrogen fertilization. It is apparent of the $1^{\text {st }}$ cut for two seasons, but the differences among treatments were not clear in the $3^{\text {rd }}$ cuts during in the two seasons for both forage millet and guar components. On high regime of nitrogen, the process of $\mathrm{N}$ fixation by legumes reduces and in these conditions the non-legume species has more dominance and completion for limiting source (Hiebsch and Mc Collum, 1987). Under different nitrogen levels, intercropping bean with corn resulted in yield reduction of legume with increasing nitrogen fertilizer (Weilray and Mcfadden, 1991).

Generally, under different intercropping patterns, increasing level of nitrogen fertilizer till $75 \mathrm{~kg} \mathrm{~N} \mathrm{fad}^{-1}$ increased contribution of the millet crop, while contribution of the guar decreased. The cereal component crop is usually taller and has a faster growing or more extensive root system of fine roots and very competitive for soil nitrogen than the legumes which usually fix atmospheric $\mathrm{N}$ (Koohi and Nasrollahzadeh, 2014).

\section{Competitive indices}

\section{Land equivalent ratio, land equivalent coefficient and relative crowding coefficient}

Table (3), indicated that the effect of different intercropping patterns on land equivalent ratio (LER), land equivalent coefficient (LEC), relative crowding coefficient $(\mathrm{K})$ were significantly different, calculated on an average for the three cuts basis. As expected, the partial LER of both crops increased as their proportions increased in the intercropping patterns at the different planting patterns. The total LER values at $2 \mathrm{M}: 1 \mathrm{G}$ were greater than unity and superior to other patterns, the values were 1.40 in the $1^{\text {st }}$ and 1.36 in the $2^{\text {nd }}$ seasons, respectively. The average relative crowding coefficient $(\mathrm{K})$ values of forage millet were higher than guar, thus indicating its dominance in the intercropping and such result is confirmed that cereals are usually more competitive than legume. These results are supported by finding of Ghosh (2004) in groundnut/cereal fodder intercropping. The crowding coefficients values were significantly different at the different intercropping patterns. However, the total $\mathrm{K}$ values at $1 \mathrm{M}: 2 \mathrm{G}$ were less 1 , thereby indicating that the crops produced less yields than expected presumably due to inadequate utilization of resources. This is consistent with the $1^{\text {st }}$ and the $2^{\text {nd }}$ season. Willey and Rao (1980) reported that the relative crowding coefficient of particular crop species is less than, equal to greater than 1 , then that species produced less yield, the same yield or more than "expected" yield, respectively. 


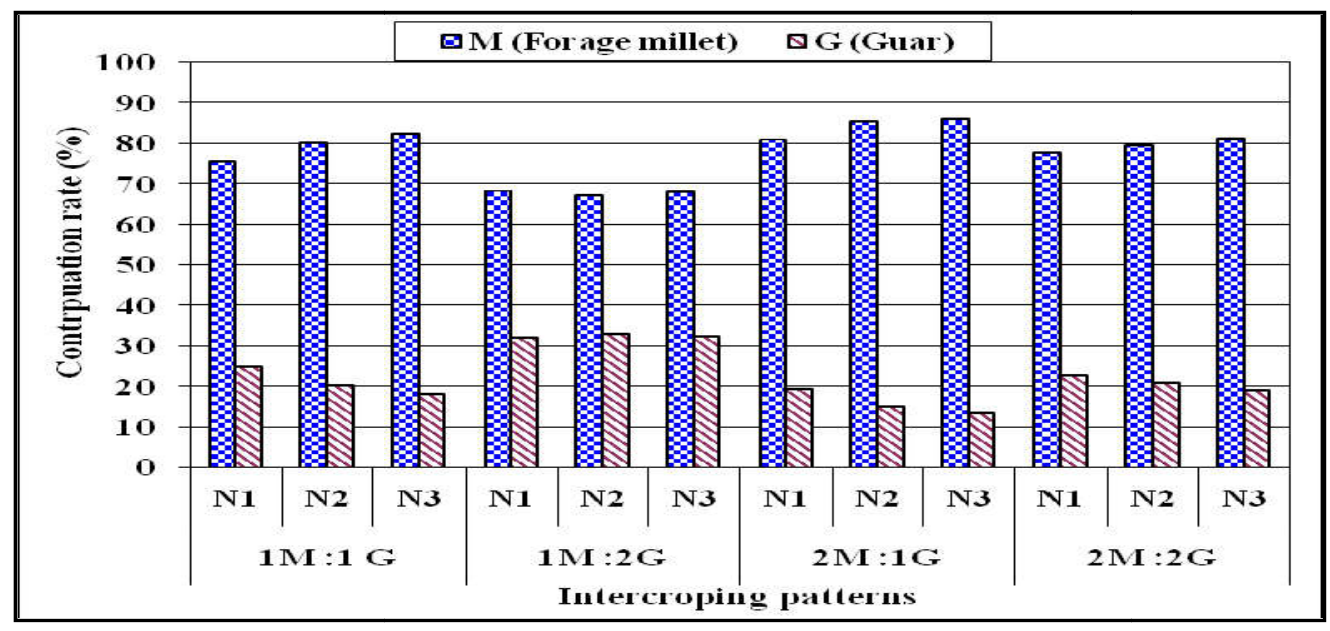

Fig. (1): Effect of intercropping pattern and nitrogen level on the contribution percentage of forage millet and guar calculated on dry forage yield basis $\left(1^{\text {st }}\right.$ cut for $1^{\text {st }}$ season $)$

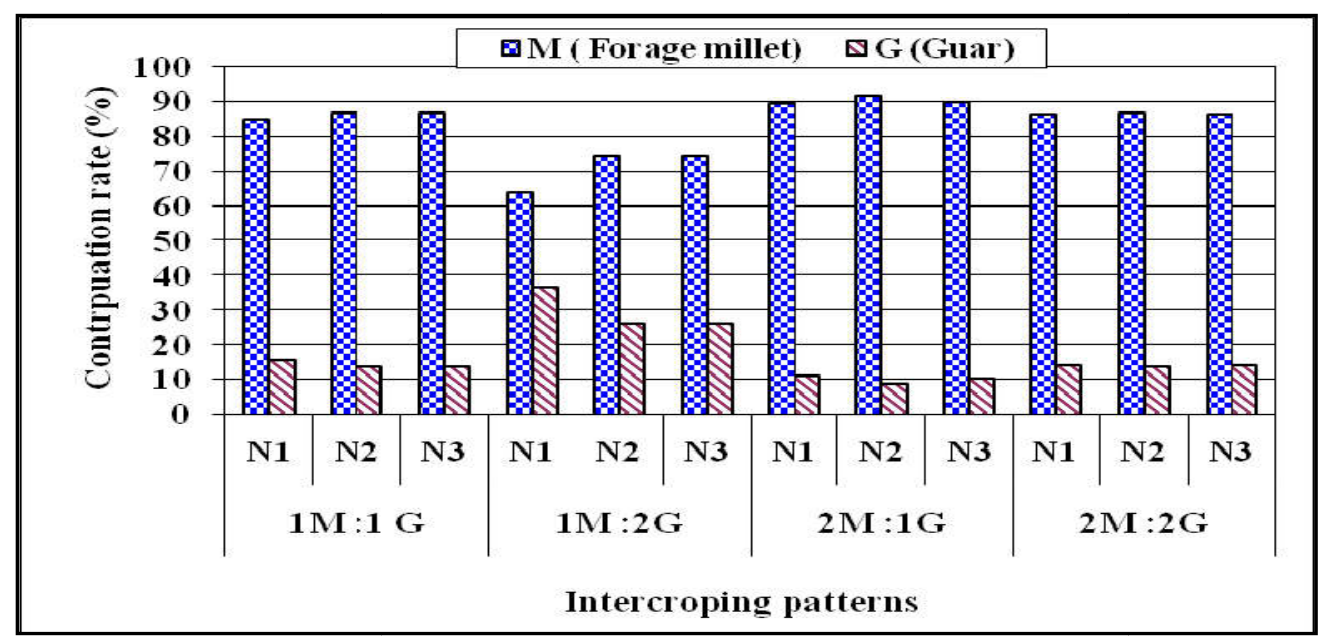

Fig. (2): Effect of intercropping pattern and nitrogen level on the contribution percentage of forage millet and guar calculated on dry forage yield basis $\left(2^{\text {nd }}\right.$ cut for $1^{\text {st }}$ season $)$

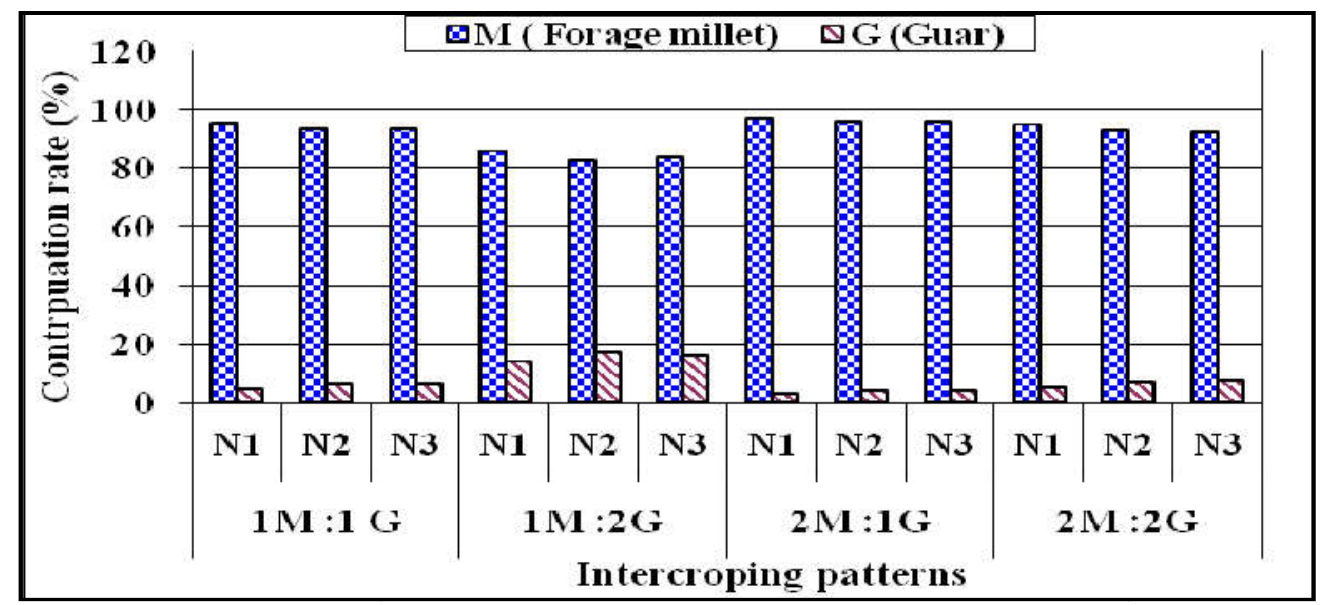

Fig. (3): Effect of intercropping pattern and nitrogen level on the contribution percentage of forage millet and guar calculated on dry forage yield basis $\left(3^{\text {rd }}\right.$ cut for $1^{\text {st }}$ season) 


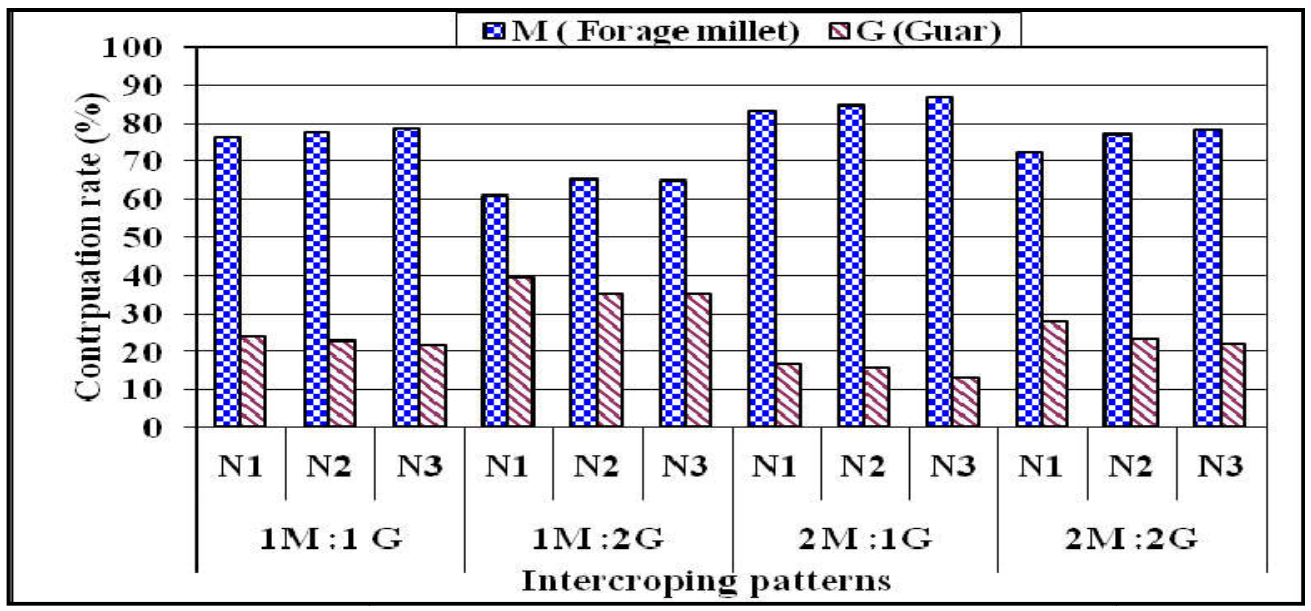

Fig. (4): Effect of intercropping pattern and nitrogen level on the contribution percentage of forage millet and guar calculated on dry forage yield basis $\left(1^{\text {st }}\right.$ cut for $2^{\text {nd }}$ season $)$

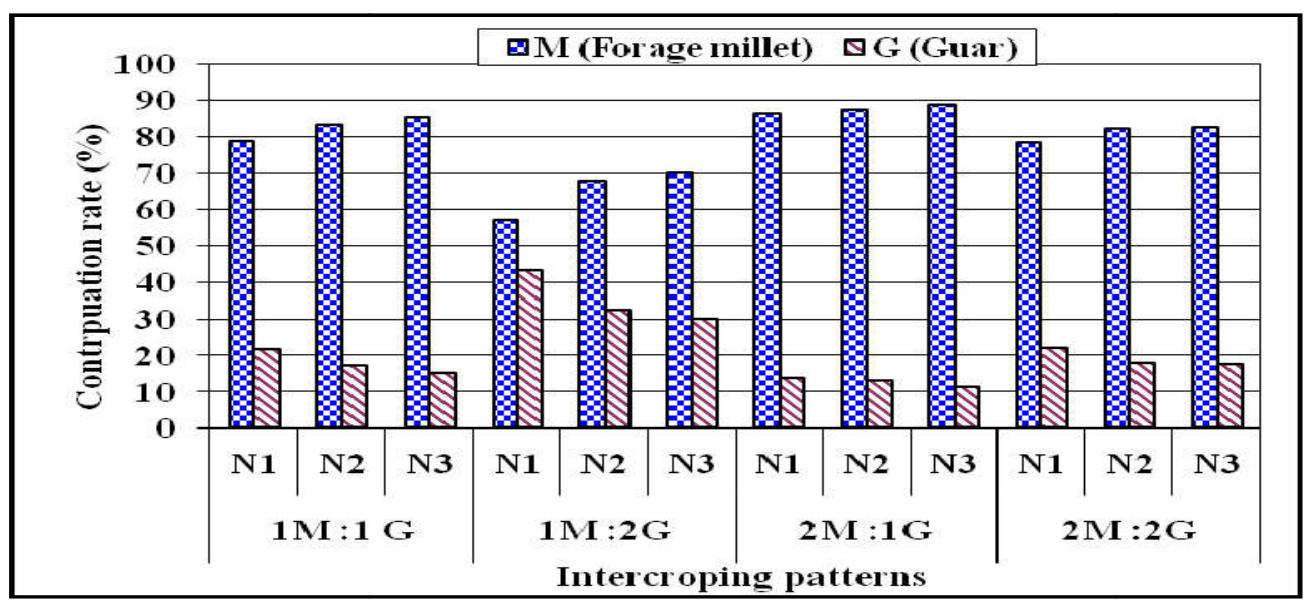

Fig. (5): Effect of intercropping pattern and nitrogen level on the contribution percentage of forage millet and guar calculated on dry forage yield basis $\left(2^{\text {nd }}\right.$ cut for $2^{\text {nd }}$ season)

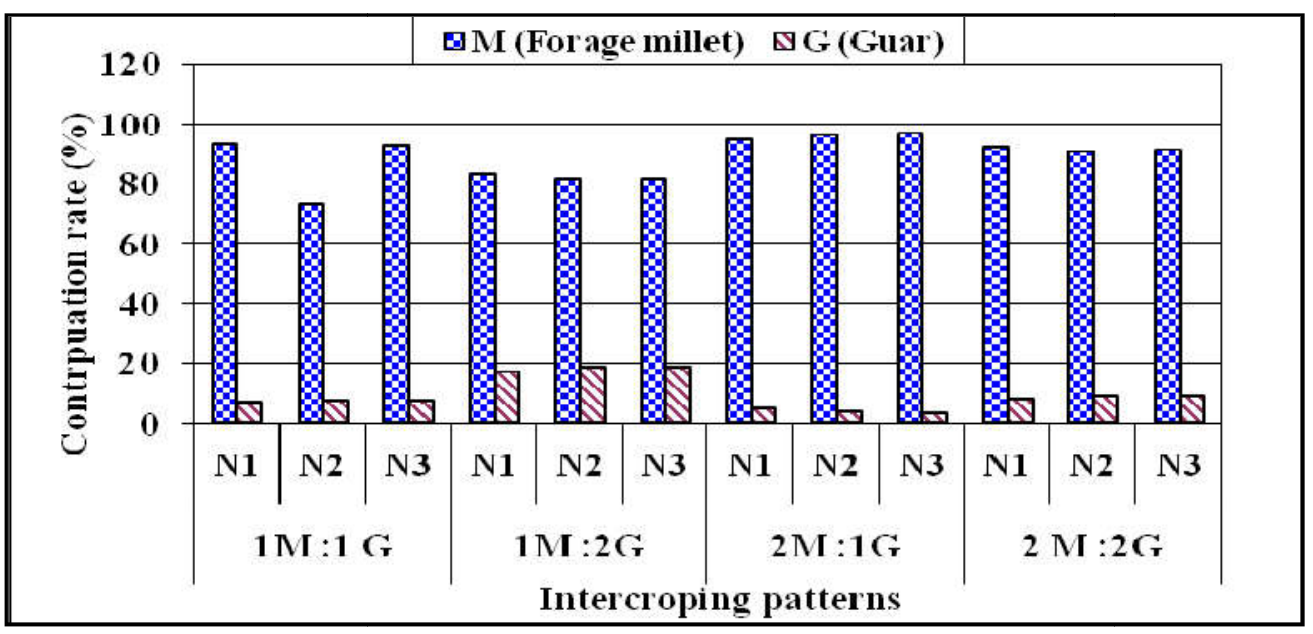

Fig. (6): Effect of intercropping pattern and nitrogen level on the contribution percentage of forage millet and guar calculated on dry forage yield basis $\left(3^{\text {rd }}\right.$ cut for $2^{\text {nd }}$ season $)$ 


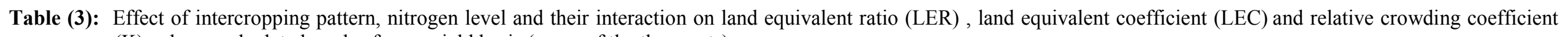
(K) values, calculated on dry forage yield basis (mean of the three cuts)

\begin{tabular}{|c|c|c|c|c|c|c|c|c|c|c|c|c|c|c|c|c|c|c|}
\hline \multirow{2}{*}{ Main effects and interactions } & \multicolumn{9}{|c|}{ First season } & \multicolumn{9}{|c|}{ Second season } \\
\hline & $\mathbf{L E}_{\mathbf{m}}$ & $\mathbf{L E}_{\mathrm{g}}$ & LER & $\mathbf{L} \mathbf{E}_{\mathbf{m}}$ & $\mathbf{L E}_{\mathbf{g}}$ & LEC & $\mathbf{K}_{\mathbf{m}}$ & $\mathbf{K}_{\mathbf{g}}$ & $\mathbf{K}$ & $\mathbf{L E}_{\mathbf{m}}$ & $\mathbf{L E}_{\mathrm{g}}$ & LER & $\mathbf{L E}_{\mathbf{m}}$ & $\mathbf{L E}_{\mathbf{g}}$ & LEC & $\mathbf{K}_{\mathbf{m}}$ & $\mathbf{K}_{\mathrm{g}}$ & $\mathbf{K}$ \\
\hline \multicolumn{19}{|l|}{ Intercropping pattern (A) } \\
\hline 1: 1 Forage millet / guar (A1) & 0.75 & 0.48 & 1.23 & 0.75 & 0.48 & 0.36 & 1.56 & 0.62 & 0.97 & 0.75 & 0.47 & 1.24 & 0.75 & 0.47 & 0.36 & 1.72 & 0.60 & 1.00 \\
\hline $1: 2$ Forage millet / guar (A2) & 0.48 & 0.69 & 1.18 & 0.48 & 0.69 & 0.33 & 1.28 & 0.71 & 0.88 & 0.48 & 0.70 & 1.18 & 0.48 & 0.70 & 0.33 & 1.51 & 0.60 & 0.88 \\
\hline 2:1 Forage millet / guar (A3) & 0.98 & 0.41 & 1.40 & 0.98 & 0.41 & 0.41 & 1.90 & 0.85 & 1.75 & 0.97 & 0.38 & 1.36 & 0.97 & 0.38 & 0.37 & 2.04 & 0.73 & 1.40 \\
\hline 2:2 Forage millet / guar (A4) & 0.79 & 0.51 & 1.31 & 0.79 & 0.51 & 0.40 & 1.80 & 0.69 & 1.31 & 0.74 & 0.51 & 1.25 & 0.74 & 0.51 & 0.37 & 1.78 & 0.67 & 1.16 \\
\hline LSD 0.05 & 0.02 & 0.07 & 0.06 & 0.02 & 0.07 & 0.04 & 0.36 & NS & 0.40 & 0.02 & 0.04 & 0.04 & 0.02 & 0.04 & 0.02 & 0.32 & NS & 0.21 \\
\hline \multicolumn{19}{|l|}{ Nitrogen level (B) } \\
\hline $45 \mathrm{~kg} \mathrm{~N} \mathrm{fad}^{-1}$. (B1) & 0.73 & 0.52 & 1.26 & 0.73 & 0.52 & 0.36 & 1.50 & 0.68 & 1.07 & 0.68 & 0.48 & 1.17 & 0.68 & 0.48 & 0.30 & 1.59 & 0.69 & 1.04 \\
\hline 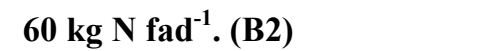 & 0.76 & 0.52 & 1.28 & 0.76 & 0.52 & 0.37 & 1.69 & 0.71 & 1.26 & 0.75 & 0.52 & 1.28 & 0.75 & 0.52 & 0.37 & 1.80 & 0.64 & 1.12 \\
\hline $75 \mathrm{~kg} \mathrm{Nfad}^{-1} .(\mathrm{B3})$ & 0.77 & 0.53 & 1.31 & 0.77 & 0.53 & 0.39 & 1.71 & 0.76 & 1.35 & 0.77 & 0.54 & 1.32 & 0.77 & 0.54 & 0.40 & 1.90 & 0.62 & 1.18 \\
\hline LSD 0.05 & 0.02 & NS & 0.03 & 0.02 & NS & 0.02 & 0.12 & NS & 0.12 & 0.04 & 0.04 & 0.04 & 0.04 & 0.04 & 0.03 & 0.20 & $\mathrm{NS}$ & 0.08 \\
\hline \multicolumn{19}{|l|}{ Interaction } \\
\hline A1B1 & 0.74 & 0.51 & 1.25 & 0.74 & 0.51 & 0.37 & 1.37 & 0.64 & 0.91 & 0.74 & 0.47 & 1.21 & 0.74 & 0.47 & 0.35 & 1.56 & 0.65 & 0.92 \\
\hline A1B2 & 0.76 & 0.47 & 1.23 & 0.76 & 0.47 & 0.36 & 1.66 & 0.61 & 0.99 & 0.75 & 0.47 & 1.23 & 0.75 & 0.47 & 0.35 & 1.78 & 0.56 & 0.98 \\
\hline A1B3 & 0.75 & 0.45 & 1.21 & 0.75 & 0.45 & 0.35 & 1.64 & 0.62 & 1.01 & 0.78 & 0.48 & 1.27 & 0.78 & 0.48 & 0.37 & 1.84 & 0.61 & 1.09 \\
\hline A2B1 & 0.44 & 0.65 & 1.10 & 0.44 & 0.65 & 0.28 & 1.30 & 0.67 & 0.83 & 0.42 & 0.62 & 1.05 & 0.42 & 0.62 & 0.25 & 1.31 & 0.67 & 0.80 \\
\hline A2B2 & 0.50 & 0.72 & 1.22 & 0.50 & 0.72 & 0.35 & 1.28 & 0.69 & 0.86 & 0.50 & 0.71 & 1.22 & 0.50 & 0.71 & 0.35 & 1.65 & 0.56 & 0.90 \\
\hline A2B3 & 0.50 & 0.72 & 1.23 & 0.50 & 0.72 & 0.36 & 1.26 & 0.77 & 0.93 & 0.52 & 0.76 & 1.29 & 0.52 & 0.76 & 0.40 & 1.57 & 0.59 & 0.94 \\
\hline A3B1 & 0.93 & 0.43 & 1.36 & 0.93 & 0.43 & 0.39 & 1.66 & 0.88 & 1.56 & 0.91 & 0.37 & 1.30 & 0.91 & 0.37 & 0.34 & 1.70 & 0.82 & 1.32 \\
\hline A3B2 & 0.98 & 0.38 & 1.37 & 0.98 & 0.38 & 0.39 & 1.98 & 0.80 & 1.74 & 0.96 & 0.38 & 1.35 & 0.96 & 0.38 & 0.36 & 2.05 & 0.74 & 1.40 \\
\hline A3B3 & 1.05 & 0.44 & 1.49 & 1.05 & 0.44 & 0.46 & 2.06 & 0.87 & 1.94 & 1.03 & 0.39 & 1.42 & 1.03 & 0.39 & 0.40 & 2.38 & 0.64 & 1.48 \\
\hline A4B1 & 0.81 & 0.5 & 1.31 & 0.81 & 0.5 & 0.40 & 1.66 & 0.52 & 0.97 & 0.65 & 0.46 & 1.12 & 0.65 & 0.46 & 0.29 & 1.79 & 0.65 & 1.11 \\
\hline A4B2 & 0.80 & 0.51 & 1.31 & 0.80 & 0.51 & 0.41 & 1.84 & 0.75 & 1.45 & 0.79 & 0.52 & 1.32 & 0.79 & 0.52 & 0.41 & 1.75 & 0.70 & 1.19 \\
\hline A4B3 & 0.78 & 0.52 & 1.31 & 0.78 & 0.52 & 0.41 & 1.89 & 0.79 & 1.53 & 0.77 & 0.55 & 1.33 & 0.77 & 0.55 & 0.42 & 1.81 & 0.67 & 1.20 \\
\hline LSD 0.05 & NS & $\mathrm{NS}$ & 0.07 & $\mathrm{NS}$ & NS & 0.05 & NS & NS & $\mathrm{NS}$ & $\mathrm{NS}$ & $\mathrm{NS}$ & 0.05 & $\mathrm{NS}$ & NS & $\mathrm{NS}$ & NS & $\mathrm{NS}$ & NS \\
\hline
\end{tabular}


Regarding the effect of nitrogen levels on LER, LEC and K of forage millet-guar intercropping pattern, the statistical analysis for the values of LER showed significant differences among the nitrogen levels for the average of the three cuts in both seasons. LER values were greater than one even at the lowest used level of nitrogen fertilization, and this was true in both seasons. Indicating that, the partial LER of forage millet was higher than the partial LER of guar component in intercropping and that may be due to more $\mathrm{N}$ availability. Guar plants are provided symbiotically by nitrogen more effectiveness to the associated pearl millet plants under the lowest level of mineral nitrogen fertilization. The LEC values for the average of the three cuts were greater $(0.25)$ under any nitrogen level of the two seasons, indicating yield advantage for intercropping patterns and showed efficient utilization of land resource by growing both crops together and vice versa. Bejiga and Brink (2006) stated that the greater LEC of intercrops was mainly due to a greater resource use and resource complementarily, when the species were grown alone. In generally, the average relative crowding coefficient (K) had the same trend of LER. The high nitrogen level of $75 \mathrm{~kg} \mathrm{~N} \mathrm{fad}^{-1}$ gave the highest values of LER, LEC and K. However, the differences among the nitrogen level 60 and $75 \mathrm{~kg} \mathrm{~N}^{-1} \mathrm{fad}^{-1}$ were not significant in both seasons. The same result was obtained by Dahmardeh et al. (2009), Reza (2012).

The most important results concerning the effect of the interactions between intercropping patterns and nitrogen levels on LER, LEC and $\mathrm{K}$ of forage milletguar intercropping pattern. The data reveal that, under different intercropping patterns used; the LER, LEC values were increased by adding nitrogen. However, the highest LER values and cropping advantage were achieved by intercropping pattern (2M:1G) and adding $75 \mathrm{~kg} \mathrm{~N} \mathrm{fad}^{-1}$. This was true during two seasons, while the interaction effect among different studied factors on $\mathrm{K}$ values were insignificant.

\section{Aggressivety and competitive ratio and system productivity index}

Aggressivity (A), competitive ratio (CR) and system productivity index (SPI) of forage millet-guar in 4 intercropping patterns are presented in Table (4). The competitive ability of the component crops in an intercropping system is determined by its aggressivity values. Regardless of aggressivity, there was positive sign for forage millet and negative sign for the intercropped guar, indicating that forage millet was dominant. Results showed positive aggressivity for forage millet at $2 \mathrm{M}: \mathrm{IG}, 2 \mathrm{M}: 2 \mathrm{G}$ and $1 \mathrm{M}: 1 \mathrm{G}$ intercropping patterns, while it proved less competitive by guar at $1 \mathrm{M}: 2 \mathrm{G}$ intercropping pattern. Oraka and Omoregie (2007) obtained higher aggressivity in cowpea over rice at higher population densities. The competitive ratio (CR), which measures the degree with which one crop competes with other, showed that forage millet had higher competitive indices than guar in all the intercropping patterns except $1 \mathrm{M}: 2 \mathrm{G}$. The result of CR corroborates with that of aggressivity, forage millet was more competitive than guar. Increasing the density of guar in the intercropping pattern will elevate its crowding efficiency over forage millet. The system productivity index (SPI) standardized the yield of secondary crop (guar) in terms of primary crop (forage millet), also identified the combinations that utilized growth resources effectively and maintained a stable yield performance, $2 \mathrm{M}: 1 \mathrm{G}$ pattern gave the highest values of SPI than other intercropping patterns. The SPI values were 3.02 and 2.44 as the average for the three cuts in the $1^{\text {st }}$ and the $2^{\text {nd }}$ seasons, respectively.

Regarding the effect of nitrogen level on Aggressivity (A) and competitive ratio (CR) of forage millet-guar in 4 intercropping patterns over the three cuts for both seasons, it is apparent from the data in Table (4), there was positive sign for forage millet and negative sign for the intercropped guar, indicating that forage millet was dominant while guar was dominated, whereas increasing levels of $\mathrm{N}$ increased forage millet competition to guar component for space, nutrients, and solar radiation, On high regimen of nitrogen, the process of $\mathrm{N}$ fixation by legumes reduces and in these conditions the non-legume species has more dominance and completion for limiting source, this is a true in both seasons. The (A) of cereal values were more aggressive with the incremental levels of $\mathrm{N}$ due to better growth (Strydhorst et al., 2008). Clark and Myers (1994) reported that the utilization of different nitrogen levels in intercropping bean with corn resulted in yield reduction of legume with increasing nitrogen fertilizer. In general increasing $\mathrm{N}$ level applied to intercropping treatments lead to increase CR for cereal, while CR for legume started decline. On the other hand, system productivity index (SPI) values were increased significantly as $\mathrm{N}$ - application was raised from 45 to $75 \mathrm{~kg} \mathrm{Nfad}^{-1}$. Also, the highest SPI values 3.22 and 2.75 in the $1^{\text {st }}$ and the $2^{\text {nd }}$ seasons, respectively, were obtained by using $75 \mathrm{~kg} \mathrm{Nfad}^{-1}$. Nitrogen application increased number of tillers, plant height and the leaf area of plants and this ultimately leads to raise dry matter particularly for forage millet component. These results are in good agreement with those obtained by Zhao et al. (2005).

Concerning the interaction effect between the two factors under study on the aggressivity and competitive ratio, it is evident from the data in Table (4), that the values of aggressivity and competitive ratio were not significantly affected with the interaction between intercropping patterns and nitrogen levels. However, it was observed that, the forage millet component for intercropping patterns $(2 \mathrm{M}: 1 \mathrm{G}),(1 \mathrm{M}: 1 \mathrm{G})$ and $(2 \mathrm{M}: 2 \mathrm{G})$ is a funnel crop whereas, the guar component is a pentup crop under any level of nitrogen fertilization applied in the study. The interaction between intercropping patterns and nitrogen levels had significant effect on the system productivity index (SPI). The highest SPI values (3.67 and 2.94) were obtained by intercropping pattern (2M:1G) and adding $75 \mathrm{~kg} \mathrm{~N} \mathrm{fad}^{-1}$ in the $1^{\text {st }}$ and the $2^{\text {nd }}$ seasons, respectively.

\section{Economic Evaluation}

Results in Table (5), showed that the highest net return (7456 L.E.) was achieved by treatment (2M:1G intercropping pattern with75 $\mathrm{kg} \mathrm{N} \mathrm{fad}^{-1}$ ) followed by treatment (2M:1G intercropping pattern with $60 \mathrm{~kg} \mathrm{~N}$ fad $^{-1}$ ) (6371 L.E.) then treatment (2M:2G intercropping pattern with $75 \mathrm{~kg} \mathrm{~N}^{-1}$ ) (5821 L.E.), while, the treatment (1M:2G intercropping pattern with $45 \mathrm{~kg} \mathrm{~N}$ fad $^{-1}$ ) (1136) produced the lowest net return and net return of invested Egyptian pound. 
Table (4): Effect of intercropping pattern, nitrogen level and their interaction on Aggressivity (A), competitive ratio (CR) and system productivity index (SPI) values, calculated on dry forage yield basis (mean of the three cuts)

\begin{tabular}{|c|c|c|c|c|c|c|c|c|c|c|}
\hline \multirow{2}{*}{ Main effects and interactions } & \multicolumn{5}{|c|}{ First season } & \multicolumn{5}{|c|}{ Second season } \\
\hline & $\mathbf{A}_{\mathrm{m}}$ & $\mathbf{A}_{\mathrm{g}}$ & $\mathbf{C} \mathbf{R}_{\mathrm{m}}$ & $\mathbf{C R}_{\mathrm{g}}$ & SPI & $\mathbf{A}_{\mathrm{m}}$ & $\mathbf{A}_{\mathrm{g}}$ & $\mathbf{C R}_{\mathrm{m}}$ & $\mathbf{C R}_{\mathrm{g}}$ & SPI \\
\hline \multicolumn{11}{|l|}{ Intercropping pattern (A) } \\
\hline 1:1 Forage millet / guar (A1) & 0.54 & -0.54 & 1.73 & 0.62 & 2.65 & 0.56 & -0.56 & 1.95 & 0.61 & 2.22 \\
\hline 1:2 Forage millet / guar (A2) & 0.86 & -0.86 & 0.35 & 2.88 & 2.51 & 0.91 & -0.91 & 0.38 & 2.85 & 2.13 \\
\hline 2:1 Forage millet / guar (A3) & 1.56 & -1.56 & 5.41 & 0.20 & 3.02 & 1.55 & $1.55-$ & 6.11 & 0.18 & 2.44 \\
\hline 2:2 Forage millet / guar (A4) & 0.57 & -0.57 & 1.7 & 0.62 & 2.79 & 0.50 & $0.50-$ & 1.74 & 0.68 & 2.31 \\
\hline LSD 0.05 & 0.35 & 0.35 & 1.58 & 0.21 & 0.20 & 0.66 & 0.66 & 2.41 & 0.53 & 0.10 \\
\hline \multicolumn{11}{|l|}{ Nitrogen level (B) } \\
\hline $45 \mathrm{~kg} \mathrm{~N} \mathrm{fad}^{-1} .(\mathrm{B} 1)$ & 0.81 & -0.81 & 2.24 & 1.14 & 2.15 & 0.83 & -0.83 & 2.82 & 1.14 & 1.76 \\
\hline $60 \mathrm{~kg} \mathrm{~N} \mathrm{fad}^{-1} .(\mathrm{B} 2)$ & 0.91 & -0.91 & 2.32 & 1.06 & 2.86 & 0.88 & -0.88 & 2.41 & 1.04 & 2.33 \\
\hline $75 \mathrm{~kg} \mathrm{Nfad}^{-1} \cdot(\mathrm{B3})$ & 0.93 & -0.93 & 2.33 & 1.05 & 3.22 & 0.92 & -0.92 & 2.40 & 1.07 & 2.75 \\
\hline LSD 0.05 & 0.01 & 0.01 & 0.02 & 0.01 & 0.14 & 0.03 & 0.03 & NS & 0.01 & 0.22 \\
\hline \multicolumn{11}{|l|}{ Interaction } \\
\hline A1B1 & 0.48 & -0.48 & 1.69 & 0.67 & 2.18 & 0.53 & -0.53 & 2.27 & 0.62 & 1.82 \\
\hline A1B2 & 0.55 & -0.55 & 1.73 & 0.61 & 2.77 & 0.56 & -0.56 & 1.79 & 0.61 & 2.23 \\
\hline A1B3 & 0.61 & -0.61 & 1.76 & 0.58 & 3.00 & 0.59 & -0.59 & 1.78 & 0.59 & 2.62 \\
\hline A2B1 & 0.72 & -0.72 & 0.35 & 3.04 & 1.85 & 0.83 & -0.83 & 0.41 & 3.02 & 1.56 \\
\hline A2B2 & 0.94 & -0.94 & 0.36 & 2.82 & 2.69 & 0.90 & -0.90 & 0.38 & 2.71 & 2.21 \\
\hline A2B3 & 0.93 & -0.93 & 0.35 & 2.79 & 3.00 & 1.00 & -1.00 & 0.35 & 2.82 & 2.64 \\
\hline A3B1 & 1.43 & -1.43 & 5.15 & 0.22 & 2.34 & 1.45 & -1.45 & 6.58 & 0.19 & 1.94 \\
\hline A3B2 & 1.58 & -1.58 & 5.54 & 0.19 & 3.05 & 1.54 & -1.54 & 5.82 & 0.19 & 2.45 \\
\hline A3B3 & 1.66 & -1.66 & 5.54 & 0.19 & 3.67 & 1.66 & -1.66 & 5.93 & 0.18 & 2.94 \\
\hline A4B1 & 0.62 & -0.62 & 1.79 & 0.62 & 2.24 & 0.53 & -0.53 & 2.03 & 0.73 & 1.72 \\
\hline A4B2 & 0.56 & -0.56 & 1.64 & 0.62 & 2.93 & 0.54 & -0.54 & 1.66 & 0.64 & 2.42 \\
\hline A4B3 & 0.52 & -0.52 & 1.65 & 0.63 & 3.21 & 0.43 & -0.43 & 1.52 & 0.68 & 2.80 \\
\hline LSD 0.05 & NS & NS & NS & NS & 0.36 & NS & NS & NS & NS & 0.11 \\
\hline
\end{tabular}




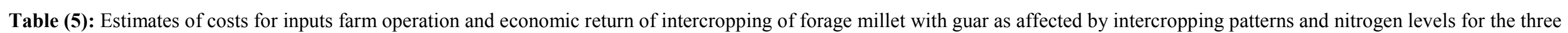
cuts across the two growing seasons

\begin{tabular}{|c|c|c|c|c|c|c|c|c|c|c|c|c|}
\hline \multirow{3}{*}{$\begin{array}{l}\text { Costs and production } \\
\text { inputs }\end{array}$} & \multicolumn{9}{|c|}{ Treatments } & & & \\
\hline & \multicolumn{3}{|c|}{$1 \mathrm{M}: 1 \mathrm{G}$ intercropping pattern } & \multicolumn{3}{|c|}{ 1M:2G intercropping pattern } & \multicolumn{3}{|c|}{ 2M:1G intercropping pattern } & \multicolumn{3}{|c|}{ 2M:2G intercropping pattern } \\
\hline & $45 \mathrm{~kg} \mathrm{~N}$ fad $^{-1}$ & $60 \mathrm{~N} \mathrm{fad}^{-1}$ & $75 \mathrm{~N} \mathrm{fad}^{-1}$ & $45 \mathrm{~N} \mathrm{fad}^{-1}$ & $60 \mathrm{~N} \mathrm{fad}^{-1}$ & $75 \mathrm{~N} \mathrm{fad}^{-1}$ & $45 \mathrm{~N} \mathrm{fad}^{-1}$ & $60 \mathrm{~N}$ fad $^{-1}$ & $75 \mathrm{~N} \mathrm{fad}^{-1}$ & $45 \mathrm{~N} \mathrm{fad}^{-1}$ & $\begin{array}{l}60 \mathrm{~N} \\
\mathrm{fad}^{-1}\end{array}$ & $\begin{array}{l}75 \mathrm{~N} \\
\mathrm{fad}^{-1}\end{array}$ \\
\hline $\begin{array}{l}\text { Land preparation } \\
\text { tillage }\end{array}$ & 550 & 550 & 550 & 550 & 550 & 550 & 550 & 550 & 550 & 550 & 550 & 550 \\
\hline planting & 400 & 400 & 400 & 400 & 400 & 400 & 400 & 400 & 400 & 400 & 400 & 400 \\
\hline Seeds & 675 & 675 & 675 & 650 & 650 & 650 & 700 & 700 & 700 & 675 & 675 & 675 \\
\hline Irrigation & 1500 & 1500 & 1500 & 1500 & 1500 & 1500 & 1500 & 1500 & 1500 & 1500 & 1500 & 1500 \\
\hline $\mathbf{N}$ & 416 & 555 & 694 & 416 & 555 & 694 & 416 & 555 & 694 & 416 & 555 & 694 \\
\hline $\mathbf{P}$ & 360 & 360 & 360 & 360 & 360 & 360 & 360 & 360 & 360 & 360 & 360 & 360 \\
\hline $\mathbf{K}$ & 400 & 400 & 400 & 400 & 400 & 400 & 400 & 400 & 400 & 400 & 400 & 400 \\
\hline Hoeing and weeding & 600 & 600 & 600 & 600 & 600 & 600 & 600 & 600 & 600 & 600 & 600 & 600 \\
\hline Harvesting & 1200 & 1200 & 1200 & 1200 & 1200 & 1200 & 1200 & 1200 & 1200 & 1200 & 1200 & 1200 \\
\hline Total variable cost & 6101 & 6240 & 6379 & 6076 & 6215 & 6354 & 6126 & 6265 & 6404 & 6101 & 6240 & 6379 \\
\hline Yield ton fad $^{-1}$ & 20.42 & 25.30 & 28.47 & 18.03 & 21.47 & 24.34 & 24.37 & 31.59 & 34.65 & 21.34 & 27.93 & 30.50 \\
\hline Price ton fad $^{-1}$ & 400 & 400 & 400 & 400 & 400 & 400 & 400 & 400 & 400 & 400 & 400 & 400 \\
\hline Total revenue & 8168 & 10120 & 11388 & 7212 & 8588 & 9736 & 9748 & 12636 & 13860 & 8536 & 11172 & 12200 \\
\hline Net return & 2067 & 3880 & 5009 & 1136 & 2373 & 3382 & 3622 & 6371 & 7456 & 2435 & 4932 & 5821 \\
\hline Return invested L.E. & 1.33 & 1.62 & 1.79 & 1.19 & 1.38 & 1.53 & 1.59 & 2.02 & 2.16 & 1.40 & 1.79 & 1.91 \\
\hline $\begin{array}{l}\text { Net Return of } \\
\text { invested L.E. }\end{array}$ & 0.33 & 0.62 & 0.79 & 0.19 & 0.38 & 0.53 & 0.59 & 1.02 & 1.16 & 0.40 & 0.79 & 0.91 \\
\hline
\end{tabular}

Net return $\left(\right.$ L.E. fad $\left.\mathrm{fa}^{-1}\right)=$ Total revenue - Total variable cost $\quad$ Return of invested $=$ Total revenue $/$ Total variable cost

Net return of invested L.E.= Return of invested L.E. -1 


\section{REFERENCES}

Aditiloye, P. O., F. O. C. Ezedinma and B. N. Okigbo (1983). A land equivalent coefficient concept for the evaluation of competitive and productive interactions on simple complex mixture. Ecol. Mod., 19:27-39.

Bejiga, G. and M. Brink (2006). Cereals and Pulses. Plant Resources of Tropical Africa. Wageningen, Netherlands: PROTA Foundation/Backhuys Publishers/CTA. p. 91.

Chui, J. A. N. and R. Shibles (1983). Influence of spatial arrangements of maize on performance of an associated soybean intercrop. Field Crop Res., 8: 187-198.

Clark, K. M. and R. L. Myers (1994). Intercrop performance of pearl millet, amaranth, cowpea, soybean and guar in response to planting pattern and nitrogen fertilization. Agron. J., 86: 1097-1102.

Dahmardeh, M., A. Ghanbari, B. Syasar and M. Ramrodi (2009). Intercropping maize and cowpea as whole-crop forage. J. of Food, Agric. and Environ., 7: 505-509.

Dhima, K. V., A. A. Lithourgidis, I. B. Vasilakoglou and C. A. Dordas (2007). Competition indices of common vetch and cereal intercrops in two seeding ratio. Field Crop Res., 100: 249-256.

Dwivedi, A., I. Dev, V. Kumar, R. S. Yadav, M. Yadav and D. L. Gupta (2015). Potential role of maize-legume intercropping systems to improve soil fertility status under smallholder farming systems for sustainable agriculture in India. Int. J. of Life Sci. Biotechnology and Pharmacy Res.., 4(3): 164-169.

Ghosh, P. K. (2004). Growth, yield, competition and economics of groundnut/cereal fodder intercropping systems in the semi-arid tropics of India. Field Crops Res., 88: 227-237.

Economic Reports (2014). Field Crops Statistical year Book. Ministry of Agriculture and Land Reclamation, Egypt.

Hannah, K. A. and T. Gohain (2016). Effect of fodder and quality attributes of maize (Zea mays L.) + cowpea (Vegna unguiculat L.) intercropping and different nitrogen levels. Int. J. of Agric. Sci. and Res., (6): 349-356.

Hassan, Hend H. M. (2003). Studies on some forage mixtures. M.Sc. Thesis, Fac. of Agric. Zagazig Univ., Egypt.

Hassan, Hend H. M., Mervat R. I. Sayed and Walaa M. E. Mousa (2017). Effect of intercropping on forage yield and land use efficiency of some summer fodder crops. Zagazig J. Agric., 44(6A): 2007-2020.

Hassan, Hend H. M. (2017). Impact of mineral, organic and bio-fertilization on growth, yield and quality of fodder pearl millet. AmericanEurasian J. Agric. \& Environ. Sci., 17(6): 450-457.

Hiebsch, C. K. and R. E. McCollum (1987). Areax Time Equivalency Ratio: A method for evaluating the productivity of intercrops. Argon's., 79: 15-22.

Homayooni, H., D. Mazaheri, N. Majnoon Hosseini and M. R. Jahansooz (2005). Evaluation of Sorghum-legume intercropping under different intercropping systems. Eighth congress of crop production and plant breeding. Univ. of Giulan.

Iqbal, M. A., A. A. Iqbal, A. Z. Reza and N. Faizal (2015). Over viewing forage maize yield and quality attributes enhancement with plant nutrition management. World J. of Agric. Sci., 11(3): 128-134.

Iqbal, M. A., B. J. Bethune, I. Asif, N. A. Rana, A. Zubair, Z. K. Haroon and A. Bilal (2017). Agro-botanical response of forage sorghum soybean intercropping systems under atypical spatio-temporal pattern. Pakistan J. of Botany, 49: 987-994.

Javanmard, A., F. Shekari and H. Dehghanian (2014). Evaluation of Forage Yield and Competition Indices for Intercropped Barley and Legumes. Int. J. of Agric. and Biosystems Engineering, 8(2): 193-196.

Koohi, S. S. and S. Nasrollahzadeh (2014). Evaluation of yield and advantage indices of sorghum (Sorghum bicolor L.) and mungbean (Vigna radiate L.) intercropping systems. Int. J. Adv Biol Biom Res., 2(1): 151-160.

Kumar, S., R. K. Agrawal, A. K. Dixit, A. K. Rai, J. B. Singh and S. K. Rai (2012). Forage production technology for arable lands. Technology bull, No. 01 .

Lesoing, G. W. and C. A. Francis (1999). Strip intercropping effect on yield and yield components of corn, grain sorghum and soybean. Agro. J., 91: 807-813. http:/dx.doi.org/10.2134/agron. J .915807x.

Mead, R. and R. W. Willey (1980). The concept of LER and advantage in yields from intercropping. Exp. Agric., 16: 217-228.

Muhammad, I., R. Muhammad, S. Aamir, A. Muhammad and A. J. Muhammad (2006). Green fodder yield and quality evaluation of maize and cowpea sown alone and in combination. Agron. J., 44: 121-129.

Odo, P. E. (1991). Evaluating short and tall sorghum varieties in mixtures with cowpea in Sudan Savanna of Nigeria: LER, grain yield and system productivity index. Exp. Agric., 27: 435-441.

Oroka, F. O. and A. U. Omoregie (2007). Competition in rice-cowpea intercrops as affected by nitrogen fertilization and plant population. Scientia Agricola (Piracicaba, Braz), 64: 621-629.

Oseni, T. O. (2010). Evaluation of sorghum - cowpea intercrop productivity in Savanna agroecology using competition indices. J. of Agric. Sci., 2(3): 229-234.

Poodineh, O., M. Keighobadi, S. Dehghan and M. M. Raoofi (2014). Evaluation of intercropping system on weed management, forage quality, 
available of nitrogen and resource use. Int. J. Agric. and Crop Sci., 13: 1298-1303.

Reza, Z. O. (2012). Evaluation of quantitative and qualitative traits of forage sorghum and lime bean under different nitrogen fertilizer regimes in additive-replacement series. Int. J. Agric. Sci., 4: 223-238.

Reza, Z. O., I. Allahdadi, D. Mazaheri, G. A. Akbari, E. Jahanzad, M. Mirshekari (2012). Evaluation of quantitative and traits of forage sorghum and lima bean under different nitrogen fertilizer regimes in additive replacement series. J. of Agric. Sci., 4(6): 223-235.

Reza, Z. O., I. Allahdadi, D. Mazaheri, G. A. Akbari, E. Jahanzad, M. Mirshekari (2013). Effect of different planting proportions and nitrogen fertilizer in intercropping forage sorghum and lima bean. African Jove Agric. Res., 8(49): 6488-6498.

Safari, A. R., S. S. Hemayati, F. Salighedar and A. R. Barimavandi (2014). Yield and quality of forage corn cultivar single cross 704 in response to nitrogen fertilization and plant density. Int. J. of Biosciences, 4(10): 146:153.

Steel, R. G. D., J. H. Torrie and D. A. Dicky (1997). Principles and Procedures of Statistics, a
Biological Approach. $3^{\text {rd }}$ Ed. MacGraw Hill Book Co. New York, 172-177.

Strydhorst, S. M., J. R. King, K. J. Lopetinsky and K. Neil-Harker (2008). Forage potential barley with faba bean, lupin, or field pea. Agron. J., 100: 182-190.

Weilray, R. and M. E. McFadden (1991). Fertility and weed stress effects on performance of maize/soybean intercrop. Agron. J., 83: 717721.

Willey, R. W. (1979). Intercropping-Its Importance and Research Needs. Part 1. Competition and yield advantages. Field Crop Abstract, 32: 1-10.

Willey, R. W. and M. R. Rao (1980). A competitive ratio for quantifying competition between intercrops. Exp. Agric., 16: 117-125.

Willey, R. W., M. Matarajan, M. S. Reddy, M. R. Rao, P.T.C. Nambiar, J. Kammainan and V. S. Bhatanagar (1980). Intercropping studies with annual crops. In J. C. Homeless (Ed) "Better crops for food" (Pp 83-97). Ciba foundation symp.

Zhao, D., R. K., Raja, K. V. Gopal and R. Reddy (2005). Nitrogen deficiency effects on plant growth, leaf photosynthesis, and reflectance properties of sorghum. Eur. J. Agron., 22: 391-403.

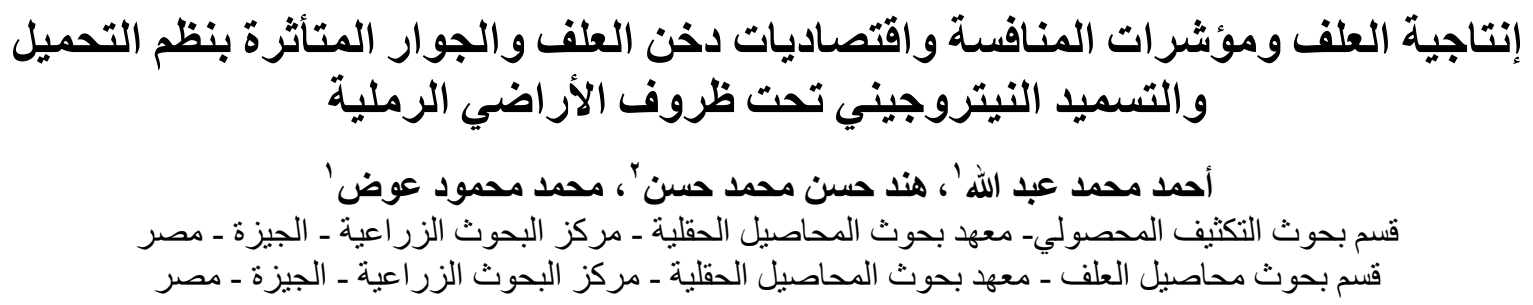

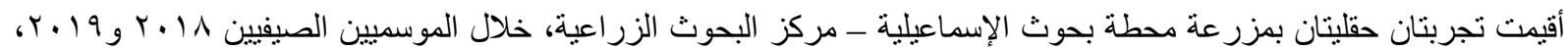

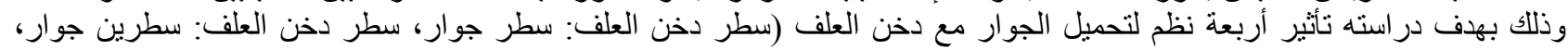

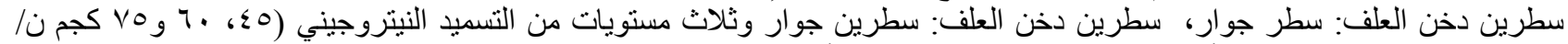

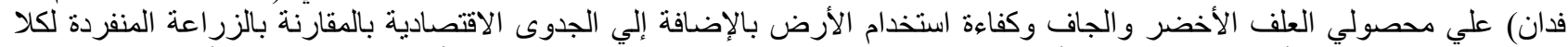

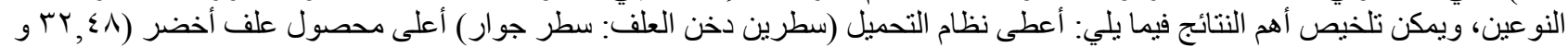

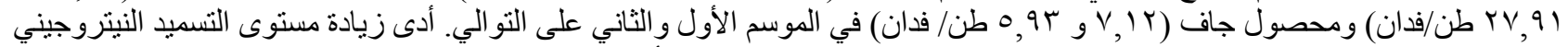

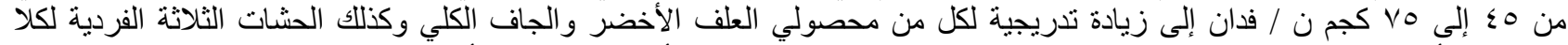

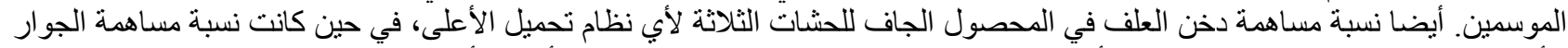

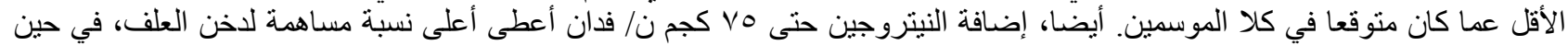

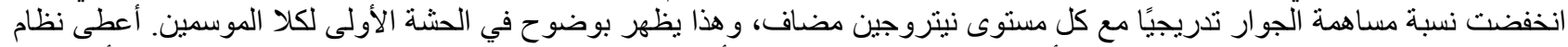

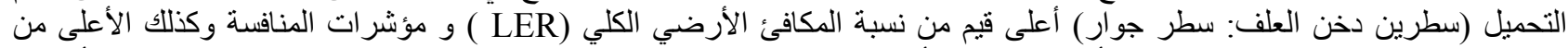

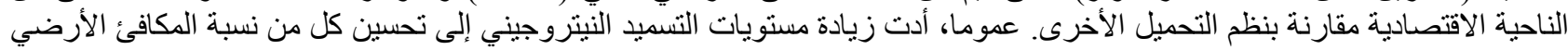

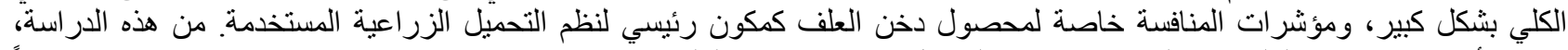

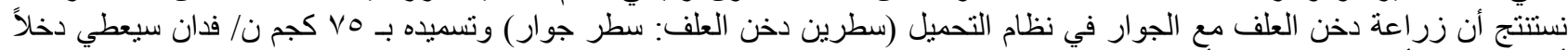

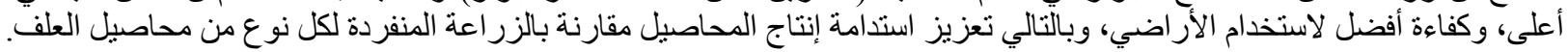

